\title{
Evaluating Croton macrostachyus: honey, nectar, and pollen antimicrobial activities against Escherichia coli, Shigella boydii, Staphylococcus aureus, and Bacillus subtilis
}

Kasim Roba ( $\nabla$ kasimroba7@gmail.com )

Holeta bee research center

\section{Zufan Bedewi}

Hawassa University College of natural and computational science

\section{Research Article}

Keywords: Antimicrobial sources, crotons honey, crotons nectar, Crotons pollen, evaluation, identification

Posted Date: February 8th, 2022

DOI: https://doi.org/10.21203/rs.3.rs-1329515/v1

License: (a) (1) This work is licensed under a Creative Commons Attribution 4.0 International License.

Read Full License 


\section{Abstract}

Background: Ethiopia is one of the plant species-rich countries in the world and the center of origin of many medicinal plants. Studying antimicrobial activities is vital to investigate plants resources for medicinal values and the study was conducted to identify and evaluate Croton macrostachyus honey's antimicrobial sources from its nectar and pollen against mentioned bacteria.

Methods: Completely Randomised Design was used for the laboratory. After adjusting turbidity, consistent growth of bacterial culture was made using sterilized cotton. The extract of $C$. macrostachyus' pollen $3.6 \mathrm{gm}$. was added to $12 \mathrm{ml}$ of distilled water to prepare stock solutions as $3.6: 12=0.3 \times B=3 \times$ a ppm stock solution and antimicrobial activities of pollen, nectar, and honey were tested against mentioned bacteria above. Data were inserted into Microsoft excel 2010 and imported to R software version 3.44. Multilevel analysis was used to see the interaction between bacteria species and each concentration of honey, nectar, and pollen of Croton and Anova was used to see the significance of these concentrations on bacteria species. A p-value of $<0.05$ was considered statistically significant.

Results: Results indicated that bacteria were more inhibited at 72 hours than 48 and 24 hours and the result identified honey's antimicrobial source was due to pollen composition found in honey that only pollen had antimicrobial activities while nectar had no antimicrobial activities against both Gramnegative and Gram-positive bacteria mentioned above. Time has significant effects on tested bacteria ( $p$ $=0.000)$ and treatments have significant effects on tested organisms $(p=0.000)$. Honey inhibited the growth of more Gram-negative bacteria: Escherichia coli and Shigella boydii. Bacillus was mostly inhibited by crotons' pollen than others.

Conclusions: Water extract of Crotons 'pollen had antibacterial activities against all tested bacterial strains, but inhibited more Gram-positive bacteria; while Crotons'honey inhibited more Gram-negative bacteria than Gram-positive bacteria. Negative controls (sterilized water) and nectar did not show an inhibitory effect on tested bacteria, while positive control (Chloramphenicol) had antimicrobial activities. Further isolation and characterization of bioactive compounds from Croton macrostachyus pollen are useful to develop a novel botanical formulation for further applications.

\section{Background}

C. macrostachyus is a species of the genus Croton., Euphorbiaceae family, commonly known as the spurge family, and croton is regarded as a multipurpose tree playing an important role in primary healthcare (2). Ethnobotanical studies on traditional medicinal plants are the means to increase the capacity of the pharmaceutical industries (4). Alternative medicine is considered as a primary health care modality in resource-constrained health care settings (6). Healing with medicinal plants is as old as mankind itself (7). Pollens are a rich source of essential amino acids and are often considered as a complete food for human beings healthy (8). According to my knowledge in this field, no data related to 
the biological activity of Crotons' pollen grain, nectar, and honey has been in literature, and to fill this gap the researcher is interested to do this research. Each flower species has a unique pollen grain (12).

Pollen-based microcapsules such as hollow sporopollenin exine capsules have emerged as excellent drug delivery and microencapsulation vehicles (14). Comparative study on the antibacterial activities of (pollen, and honey) has antibacterial efficacy against pathogenic Gram-positive and Gram-negative bacteria (15). Honey contains appropriate antioxidants which are responsible for biological activity, defense, and increase red blood cells functions and pharmaceutical and biological scientists need to identify the floral species which give anti-microbial characteristics (19). The use of honey as a traditional remedy for microbial infections dates back to ancient times (20). The reason to study the antibacterial property of honey and pollen is to find safe and natural antibiotics; since several microorganisms have developed resistance to commonly prescribed antibiotics, there is a need to find alternatives (22).

Intoxications and infections caused by food-borne pathogens like Escherichia coli represent increasing public health problems; $S$. aureus is a Gram-positive, non-spore-forming spherical bacterium that belongs to the Staphylococcus genus that subdivided into 32 species and subspecies (27). Shigella species are members of the family Enterobacteriaceae, classified based on biochemical and serological characteristics (28). The Bacillus species constitute an interesting group of probiotic bacteria that received limited attention (31).

\section{Methods}

Selected trees were caged by insects proved to avoid visiting insects to get more pollen for the experiment (34). A pollen grain of C.macrostachyus was collected when it was warm, windy, and particularly when humidity was low and preferably during the middle of the day (35). Four species of bacteria were selected for the experiment; two Gram-positive: Staphylococcus aureus and Bacillus subtilis and two-Gram negative: Escherichia coli and Shigella boydii and they were cultured. With the help of a sterile wire loop, the test bacteria were transferred into test tubes having a sterile nutrient broth and incubated at $37^{\circ} \mathrm{C}$ for 24 hours until the noticeable turbidity and density was equal to that of 0.5 McFarland standards by adding $0.5 \mathrm{ml}$ of $\mathrm{BaCl}_{2}$ solution into $99.5 \mathrm{ml}$ of $\mathrm{H}_{2} \mathrm{SO}_{4}$. After adjusting turbidity, a sterile cotton swab was dipped into suspension and streaked over the whole surface of the plate to make sure the consistent growth of bacterial culture (36).

For the extraction 10, gm. of collected pollen of croton was added to $250 \mathrm{ml}$ of beakers that contains 100 $\mathrm{ml}$ of distilled water and shaken for 24 hours and filtered by Whatman filter paper and then dried in the water bath. The extracts of Crotons' pollen were measured by sensitive balance and then stock solutions and working concentrations were prepared for its honey and pollen. It was pure honey that was used for the experiment and no need of extracting honey and only working concentrations were prepared by three different concentrations based on the amount of the extract obtained from extractions of pollen. As well, nectar was used directly in all concentrations since no need for extraction nectar. To prepare a stock solution, $3.6 \mathrm{gm}$. of the extract of C.macrostachyus'pollen was added to $12 \mathrm{ml}$ of distilled water. It was 
calculated as 3.6:12 = $0.3 x=3 x$ ppm stock solution. Working concentrations of $100 \%, 70 \%$, and $30 \%$ were prepared from stock.

Antimicrobial activities of $C$. macrostachyus'nectar, pollen, and honey were tested against mentioned bacteria after they incubated. Disks were mixed into working concentrations of $100 \%, 70 \%$, and $30 \%$ and then added to labeled bacteria species inoculated into Petri dish respectively and stayed for 10-15 minutes until introduced with media, inverted and then brought to incubator incubated at $37 \otimes \mathrm{C}$. The inhibition zone of bacteria was checked continuously for 24,48 , and 72 hours and measured at 48 and $72 \mathrm{hrs}$. The number of experiments was replicated thrice for all bacteria species and the results were inserted to computer Microsoft excel 2010 and imported to R software version 3.44. Multilevel analysis was used to see the interaction between bacteria species and each concentration of treatments and Anova was used to see the significance of these concentrations on bacteria species. A p-value of $<0.05$ was considered statistically significant.

\section{Results}

Positive control Chloramphenicol had the highest antimicrobial activities against; Bacillus subtilis and Staphylococcus aureus than Escherichia coli and Shigella boydii (Figure 1). Chloramphenicol shows more significant effects than Croton pollen $30 \%$ concentrations against mentioned bacteria

Bacillus subtilis and Staphylococcus aureus were more inhibited by Chloramphenicol than Gram-negative bacteria: Escherichia coli and Shigella boydii (Figure 2). Chloramphenicol inhibited more Gram-positive bacteria than Gram-negative bacteria. Chloramphenicol shows more significant effects than Croton pollen $70 \%$ concentrations against Gram-positive bacteria but Croton pollen $70 \%$ concentrations have more significant effects than standard drug against Gram-negative bacteria.

Bacillus subtilis and Staphylococcus aureus were more inhibited by Chloramphenicol than Gram-negative bacteria: Escherichia coli and Shigella boydii (Figure 3).Chloramphenicol shows more significant effects than Croton pollen $100 \%$ concentrations against Gram-positive bacteria but Croton pollen $100 \%$ concentrations inhibited more Gram-negative bacteria than standard drug.

A 30\% concentration of Crotons' honey shows more significant effects than Crotons' pollen $30 \%$ water extracts (Figure 4). 30\% concentrations of honey inhibited Gram-negative bacteria: Escherichia coli and Shigella boydii more than Gram-positive Bacillus: subtilis and Staphylococcus aureus.

$70 \%$ concentrations of honey show more significant effects than Croton pollen $70 \%$ water extracts against Gram-negative bacteria (Figure 5). Honey $70 \%$ concentrations inhibited more Gram-negative bacteria (Escherichia coli and Shigella boydii) more than Gram-positive (Bacillus subtilis and Staphylococcus aureus), but Crotons' pollen inhibited more Gram-positive bacteria (Bacillus subtilis).

Escherichia coli were more inhibited by honey $100 \%$ concentrations than Croton's pollen $100 \%$ water extracts (Figure 6). Crotons' pollen 100\% water extract inhibited more Gram-positive bacteria (Bacillus 
subtilis) than all the others. Croton's pollen shows more significant effects than honey against mentioned Gram-positive bacteria. Honey $100 \%$ concentrations of water extract inhibited more Gram-negative bacteria (Escherichia coli) than Gram-positive (Bacillus subtilis and Staphylococcus aureus).

Gram-positive bacteria (Bacillus subtilis and Staphylococcus aureus) were inhibited more than Gramnegative (Escherichia coli and Shigella boydii) by crotons pollen water extract (Figure 7). Gram-positive bacteria were more inhibited than Gram-negative bacteria by $100 \%$ concentration of croton pollen and highly inhibited at $\mathrm{t} 2$ than $\mathrm{t} 1$.

Bacillus subtilis and Staphylococcus aureus bacteria were inhibited more than Gram-negative (Escherichia coli and Shigella boydii) by crotons pollen water extract (Figure 8). Nectar did not inhibit either Gram-negative bacteria or Gram-positive bacteria as shown by the figure below.

Bacillus Subtilis, Staphylococcus aureus, Shigella boydiiand Escherichia coli) were inhibited by honey and it has highly significant effects on all species of bacteria on both Gram-negative and Gram-positive mentioned bacteria (Figure 9). Nectar inhibited neither Gram-negative nor Gram-positive bacteria.

Time of the experiment has highly significant effects on all species of bacteria on both Gram-negative and Gram-positive bacteria (Figure 10). Escherichia coli and Shigella boydii were mostly inhibited than Gram-positive bacteria (Bacillus subtilis and Staphylococcus aureus) by honey $100 \%$ concentration as shown in the figure below.

\section{Discussion}

The present study summarizes that Crotons macrostachyus'pollen has high antimicrobial effects against both Gram-negative and Gram-positive bacteria however; highly inhibited Gram-positive bacteria (Bacillus Subtilis, Staphylococcus aureus) than Shigella boydii and Escherichia coli) at 30, 70, and 100 working concentrations. Honey inhibited more Gram-negative bacteria than Gram-positive bacteria and his result is in line with the reports of (37). Gram-negative bacteria were more inhibited by $100 \%$ concentrations of honey than Gram-positive bacteria. This result is contrasted with the reports of (38). Pollen $100 \%$ concentrations inhibited more Gram-positive bacteria at 72 hours. The antimicrobial activity of the extract is dependent on concentration and exposure periods. Nectar did not inhibit either Gramnegative bacteria or Gram-positive bacteria that might be due to its composition nature that it is carbohydrate bees used as energy sources. This study confirmed that honey' medicinal value is due to pollen composition found in it that this study tested antimicrobial effects of honey, nectar, and pollen of croton; honey and pollen has antimicrobial effects while nectar did not show any antimicrobial effects and the study confirmed that it is because of pollen that honey enable to have medicinal uses for many diseases. This study was limited to study antimicrobial activities of croton against these mentioned bacteria and studying many indigenous plants' antimicrobial activities at against more test organisms by different concentration is important to find alternative solutions for resistant developing bacteria against prescribed drugs. 


\section{Conclusion}

In this research program antimicrobial activities of crotons pollen, honey and nectar were tested against mentioned test organisms at concentrations of 30,70,100 ppm. Crotons' pollen extract showed antibacterial activities against all tested bacterial strains at the concentrations of $30 \%, 70 \%$, and $100 \%$ and the highest inhibition zone observed on $100 \%$ concentration, but in the case of the 48 hours and $70 \%$ concentrations of $C$. pollen solution, a lower inhibition zone is observed at the time of 72 hours than 48 hours against $B$. subtilis that might be due resistance of bacteria. Our study confirmed that this Gramnegative and Gram-positive bacteria inhibition zone differs based on treatment type, working concentration prepared from a stock solution of the experiment, and exposure period of the experiment. We conclude that crotons pollen inhibited more Gram-positive bacteria: $B$. subtilis and $S$. aureus than E. coli and S. boydii. Honey inhibited more Gram-negative bacteria than Gram-positive bacteria. Honey' antimicrobial sources are from its pollen that no inhibitions were seen by the nectar that might be due to its chemical compositions since it contains carbohydrates which help bees as an energy source; while pollen inhibited both Gram-negative and Gram-positive bacteria. Pollens and honey might be an alternative natural food resource due to their preventative properties. This study is one of the first where an antimicrobial property of Crotons' pollen, nectar, and honey against Gram-negative and Grampositive bacteria species is quantified. A future study is necessary to pinpoint the functional components in a wide variety of local honey and honeybee forages and test their biological activities to find alternatives for diseases developing resistance against prescribed drugs these days that may be important solutions.

\section{Declarations}

\section{Acknowledgments}

First and foremost, I am grateful to acknowledge my advisor Dr. Zufan Bedewi, I am very much thankful to Dr. Beyene Dobo, Mr. Mosisa Daba, and Tigist for their support during laboratory experimental work.; I need to acknowledge Dr. Abiot Deddefo who was encouraging me on everything for my success and Dr. Feto Esmo Beriso general director of Oromia research institute for his help in teaching me $\mathrm{R}$ software that helped me to analyze my thesis data. I need to concede my wife Dr. Zemzem Ahmed tendered her inspiration while I was writing the paper. I need to confess researcher Osho Tibesso from the USA for his fatherly advice when I was joining Hawassa University to learn my master of science and his wife Geno and my friend researcher Muhammed Abu, Dr. Musa Jarso director of Holeta agricultural research institute and finally I need to acknowledge Oromia agricultural research institute for financial support for thesis work in all aspects

\section{Ethics approval and consent participate}

The purpose of the study was explained to Dr. Zufan Bedewi the head of the department of natural and computational science at Hawassa University, Ethiopia and she agreed to test antimicrobial activities and 
identification of honey reasons for medicinal value from its pollen and nectar against mentioned Gramnegative and Gram-positive bacteria.

\section{Funding}

The authors would like to express their deepest gratitude to the Oromia agricultural research institute as financial support with which to conduct this research

\section{Availability of data and materials}

The author declares that all other data supporting the findings of this study are available within the article and its supplementary information files.

\section{Authors' contributions}

Mr. Kasim Roba did all laboratory work and inserted data to Microsoft Excel and imported it to R software and analyzed and interpreted and wrote this paper for publication and did all necessary things. All authors have read and approved the final manuscript.

Consent for publication: Not applicable.

Competing interests: The author declares that they have no competing interests.

Publisher's Note: BMC remains neutral about jurisdictional claims in the published papers and institutional affiliations

Author details: 1. Researcher at Holeta honey bee research center, P.O. Box 22, Holeta, Ethiopia and 2. Head department of Hawassa University at college of natural and computational science, P.O. Box 05, Hawassa, Ethiopia

\section{References}

1. Tefera BN, Kim Y. Ethnobotanical study of medicinal plants in the Hawassa Zuria District, Sidama Zone, Southern Ethiopia. Ethnobotany study Med plants Hawassa Zuria Dist, Sidama Zo, South Ethiop. 2019;7:1-21.

2. Obey JK, Ngeiywa MM, Kiprono P, Omar S, Wright A Von, Kauhanen J, et al. Antimalarial Activity of Croton macrostachyus Stem Bark Extracts against Plasmodium berghei In Vivo. Antimalarial Act Crot macrostachyus Stem Bark Extract against Plasmodium berghei Vivo. 2018;2018.

3. Meresa A, Ashebir R, Gemechu W, Teka F. Ethnomedicinal uses, phytochemistry and anti-malarial effect of Croton Ethnomedicinal uses, phytochemistry and anti-malarial effect of Croton macrostachyus ( Bisana ): A review. Ethno Med uses, Phytochem anti-malarial Eff Crot Ethno Med uses, Phytochem anti- malarial Eff Crot macrostachyus (Bisana ) A Rev. 2019;(March). 
4. Chekole G. Ethnobotanical study of medicinal plants used against human ailments in Gubalafto. Ethnobotany study Med plants used against Hum ailments Gubalafto. 2017;1-29.

5. Jamshidi-Kia F, Lorigooini Z, Amini-khoei H. Medicinal plants: Past history and future perspective. Med plants Past Hist Futur Perspect. 2018;7(1):1-7.

6. Karunamoorthi K, Phil M, Jegajeevanram K, Vijayalakshmi J, Mengistie E. Traditional Medicinal Plants: A Source of Phytotherapeutic Modality in Resource-Constrained Health Care Settings. Tradit Med Plants A Source Phyther Modality Resour Heal Care Settings. 2013;18(1):67-74.

7. Petrovska BB. Historical review of medicinal plants ' usage. Hist Rev Med plants ' usage. 2012;6(11):1-6.

8. Al-yousef HM, Amina M, Alqahtani AS, Alqahtani MS, Malik A, Hatshan MR, et al. Pollen Bee Aqueous Extract-Based Synthesis of Silver and Anti-Bacterial Activities. Pollen Bee Aqueous Extr Synth Silver Anti-Bacterial Act. 2020;1-12.

9. Kieliszek M, Piwowarek K, Kot AM, Ś AC-. Trends in Food Science \& Technology Pollen and bee bread as new health-oriented products: A review. Trends Food Sci Technol Pollen bee bread as new Heal Prod A Rev. 2018;71(July 2017):170-80.

10. Nascimento AMCB, Jr GEL. Bee pollen properties: uses and potential pharmacological applications-a review. Bee pollen Prop uses potential Pharmacol Appl Rev. 2019;(September 2018):2-5.

11. Dezmirean DS, Gherman B, Zacharias I. Antimicrobial Activity of Bee Pollen Ethanolic and Methanolic Extracts on Staphylococcus aureus Bacterial Strain. 2015;(September).

12. Bryant V. The study of Pollen and its role in the honey market. study Pollen its role honey Mark. 2016; (June 2011).

13. Atwe SU, Gill HS. Pollen grains for oral vaccination. Pollen grains oral Vaccin. 2015;45-52.

14. Fan T, Park JH, Pham QA, Tan E, Mundargi RC, Potroz MG, et al. Extraction of cage-like sporopollenin exine capsules from dandelion pollen grains. Sci Rep [Internet]. 2018;(October 2017):1-11. Available from: http://dx.doi.org/10.1038/s41598-018-24336-9

15. Wax B. Comparative Study on the Antibacterial Activities of Bee Product (Propolis , Comparative Study on the Antibacterial Activities of Bee Product (Propolis, Pollen , Bee Wax and Honey ). Comp Study Antibact Act Bee Prod ( Prop , Comp Study Antibact Act Bee Prod ( Prop , Pollen, Bee Wax Honey ). 2018;(July).

16. Komosinska-vassev K, Olczyk P, Ka J, Mencner L, Olczyk K. Bee Pollen: Chemical Composition and Therapeutic Application. Bee Pollen Chem Compos Ther Appl. 2015;2015.

17. Kocot J, Luchowska-kocot D, Kurzepa J, Musik I. Review Article Antioxidant Potential of Propolis , Bee Pollen, and Royal Jelly: Possible Medical Application. Rev Artic Antioxid Potential Prop , Bee Pollen , R Jelly Possible Med Appl. 2018;2018.

18. Wasihun AG, Kasa BG. Evaluation of antibacterial activity of honey against multidrug resistant bacteria in Ayder Referral and Teaching Hospital ,. Springerplus. 2016; 
19. Ayoub S, Al-asiri SA, Latief A. Role of Honey in Modern Medicine Role of honey in modern medicine. Saudi J Biol Sci [Internet]. 2016;(February 2017). Available from: http://dx.doi.org/10.1016/j.sjbs.2016.12.010

20. Boukraa L, Abderrahi F, Ait-Abderrahim L. Antimicrobial properties of bee broducts and medicinal plants antimicrobial properties of bee products and medicinal plants. Microb Pathog Strateg Combat Them Sci Technol Educ. 2019;(January):960-70.

21. Poland N, Grecka K. Study of the Anti-Staphylococcal Potential of Honeys. Med uses Heal benefits Honey An Overv. 2018;1-23.

22. Johnston M, Mcbride M, Dahiya D, Owusu-apenten R. Antibacterial activity of Manuka honey and its components: An overview. Antibact Act Manuka honey its components An Overv. 2018;4(November):655-64.

23. Mama M, Teshome T, Detamo J. Antibacterial Activity of Honey against Methicillin-Resistant Staphylococcus aureus: A Laboratory-Based Experimental Study. Antibact Act Honey against Methicillin-Resistant Staphylococcus aureus A Lab Exp Study. 2019;2019.

24. Anthimidou E, Mossialos D. Antibacterial Activity of Greek and Cypriot Honeys Against Staphylococcus aureus and Pseudomonas aeruginosa in Comparison to Manuka Honey. Cypriot Honeys Against Staphylococcus aureus Pseudomonas aeruginosa Comp to Manuka Honey. 2013;16(1):42-7.

25. Roba K, Masresha G, Jemberie W, Nagappan R, Campus M. Journal of Coastal Life Medicine. J Coast Life Med. 2015;3(11):895-900.

26. Denisow-pietrzyk M. Biological and therapeutic properties of bee pollen: a review. Biol Ther Prop bee pollen a Rev. 2018;Biological(May).

27. Loir L. Staphylococcus aureus. 2012;(Gaze 1985):1-9.

28. Temu MM, Kaatano GM, Miyaye ND, Buhalata SN, Shushu M, Box PO. specimens of patients with bloody diarrhoea in Mwanza, Tanzania. 2007;9(3):2005-8.

29. Okechukwu EC, Amuta EU, Gberikon GM, Njoku M. Occurrence and Seasonal Variation of Escherichia coli Isolated from Unpasteurised Raw Milk and its Products Sold in Abuja Metropolis, Nigeria. 2019;8(05):1979-88.

30. Bourne JA, Li W, Id C, Id DMG. Genetic structure, antimicrobial resistance and frequency of human associated Escherichia coli sequence types among faecal isolates from healthy dogs and cats living in Canberra , Australia. 2019;1-13.

31. Ritter AC, Paula A, Correa F, Veras FF, Brandelli A. Characterization of Bacillus subtilis Available as Probiotics. Charact Bacillus subtilis Available as Probiotics. 2018;(June).

32. Adjaloo MK. Nectar production dynamics in two melliferous plant species. Nectar Prod Dyn two melliferous plant species. 2015;(January).

33. Etikan I, Musa SA, Alkassim RS. Comparison of Convenience Sampling and Purposive Sampling Comparison of Convenience Sampling and Purposive Sampling. 2017;(February). 
34. Kasim Roba. International Journal for Research in Agricultural and Food Science ISSN: 2208-2719. Int J Res Agric Food Sci ISSN 2208-2719. 2019;(11):1-13.

35. Doebl M. Fax to: 496221 / 487-68959. 2014;(June 2005).

36. Gebreyohannes G, Nyerere A, Bii C, Sbhatu DB. Determination of Antimicrobial Activity of Extracts of Indigenous Wild Mushrooms against Pathogenic Organisms. Determ Antimicrob Act Extr Indig Wild Mushrooms against Pathog Org. 2019;2019.

37. Mohapatra DP, Thakur V, Brar SK. Antibacterial Efficacy of Raw and Processed Honey. Antibact Effic Raw Process Honey. 2011;2011.

38. Almasaudi SB, Al-nahari AAM, Sayed E, El-ghany MA, Barbour E, Al SM, et al. Antimicrobial effect of different types of honey on Staphylococcus aureus. Saudi J Biol Sci [Internet]. 2017;24(6):1255-61. Available from: http://dx.doi.org/10.1016/j.sjbs.2016.08.007

\section{Figures}

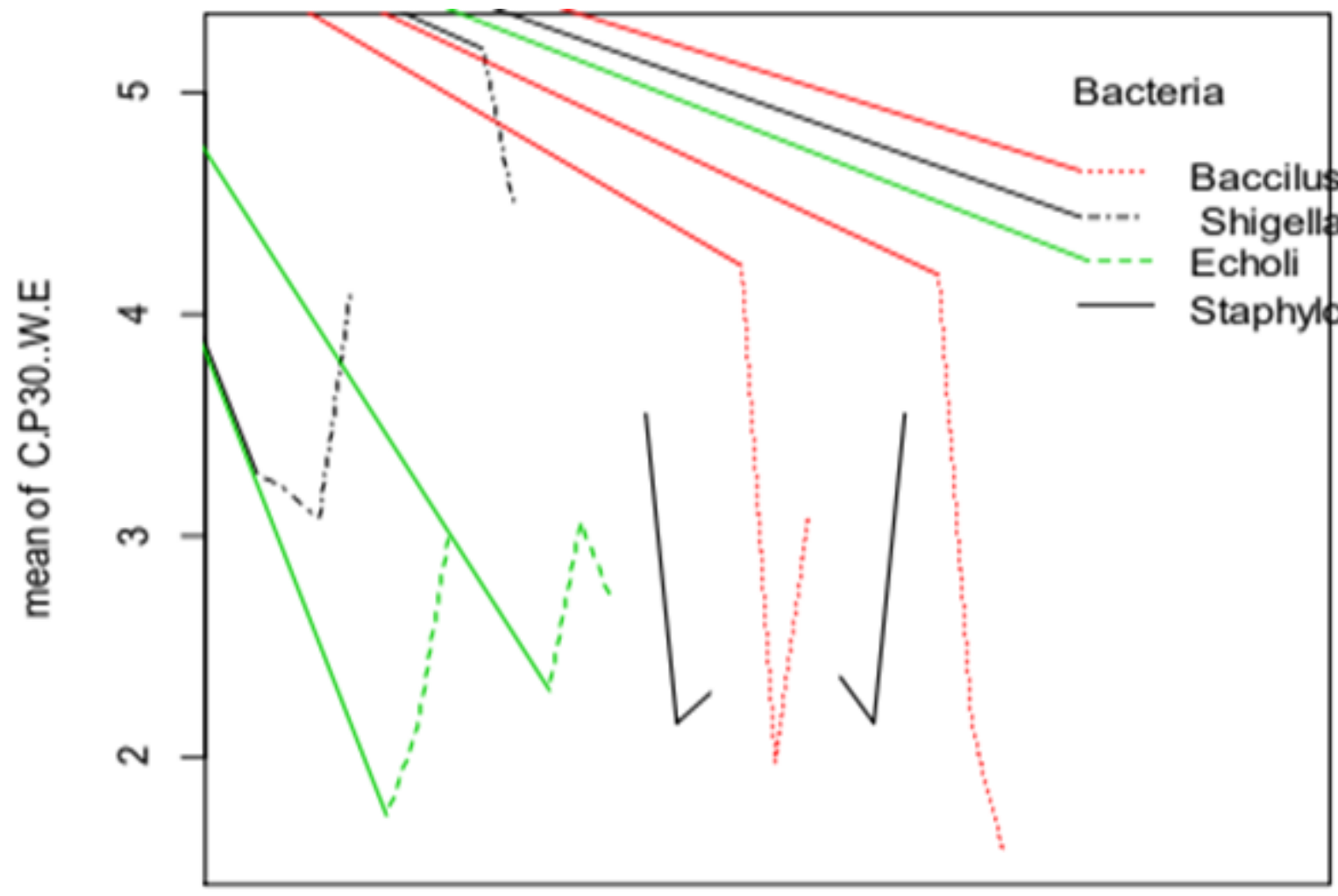

\section{$\begin{array}{llllll}6.78 & 7.98 & 12.2 & 17.31 & 21.04 & 25.2\end{array}$}

\section{Drug}

\section{Figure 1}

Interaction of Chloramphenicol, (Bacillus Subtilis, Staphylococcus aureus, Shigella boydii and Escherichia coli) and Croton pollen $30 \%$ concentrations of water extract. 


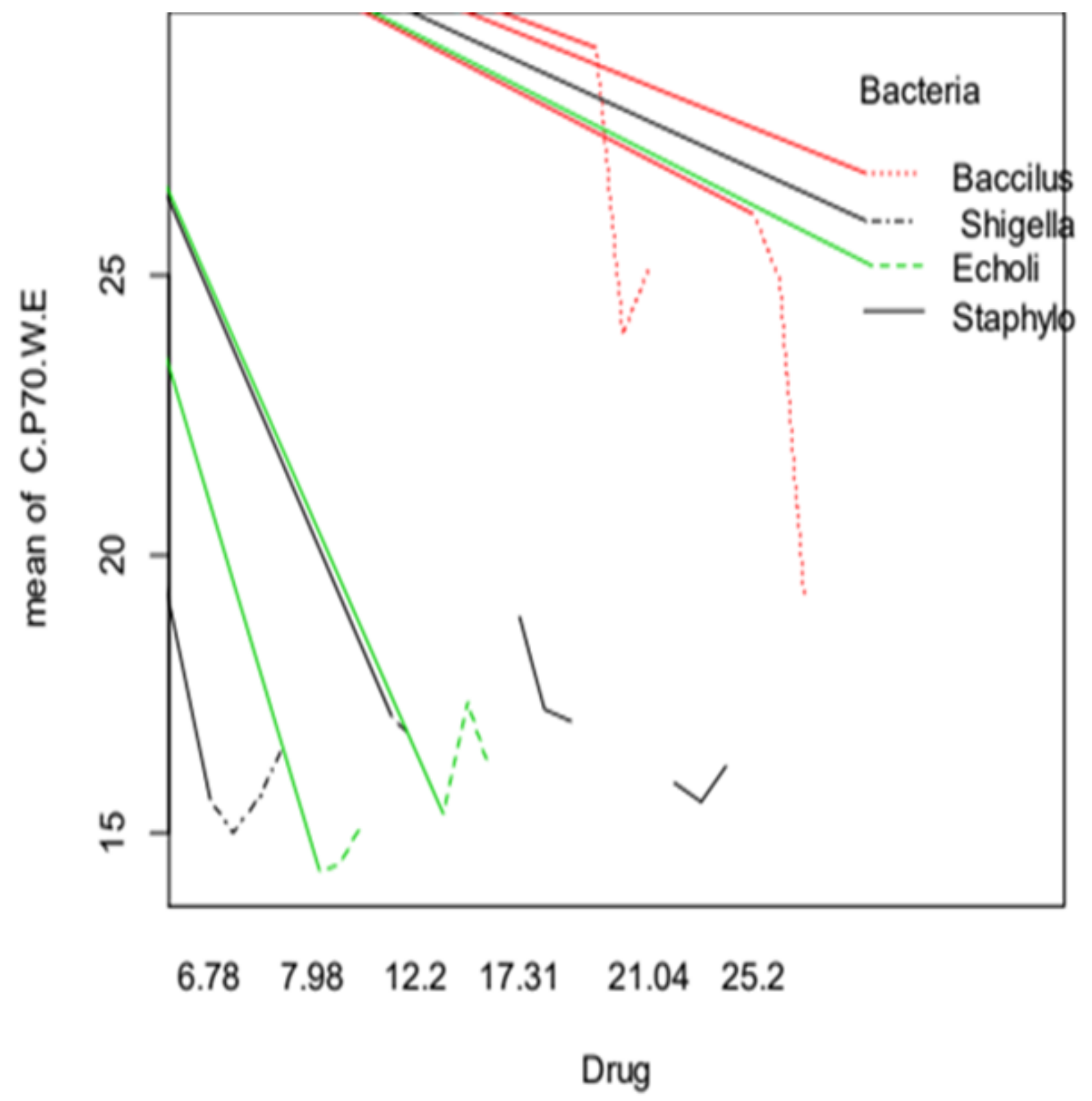

Figure 2

Interaction of Chloramphenicol, (Bacillus Subtilis, Staphylococcus aureus, Shigella boydii and Escherichia coli) and Croton pollen $70 \%$ concentrations of water extract 


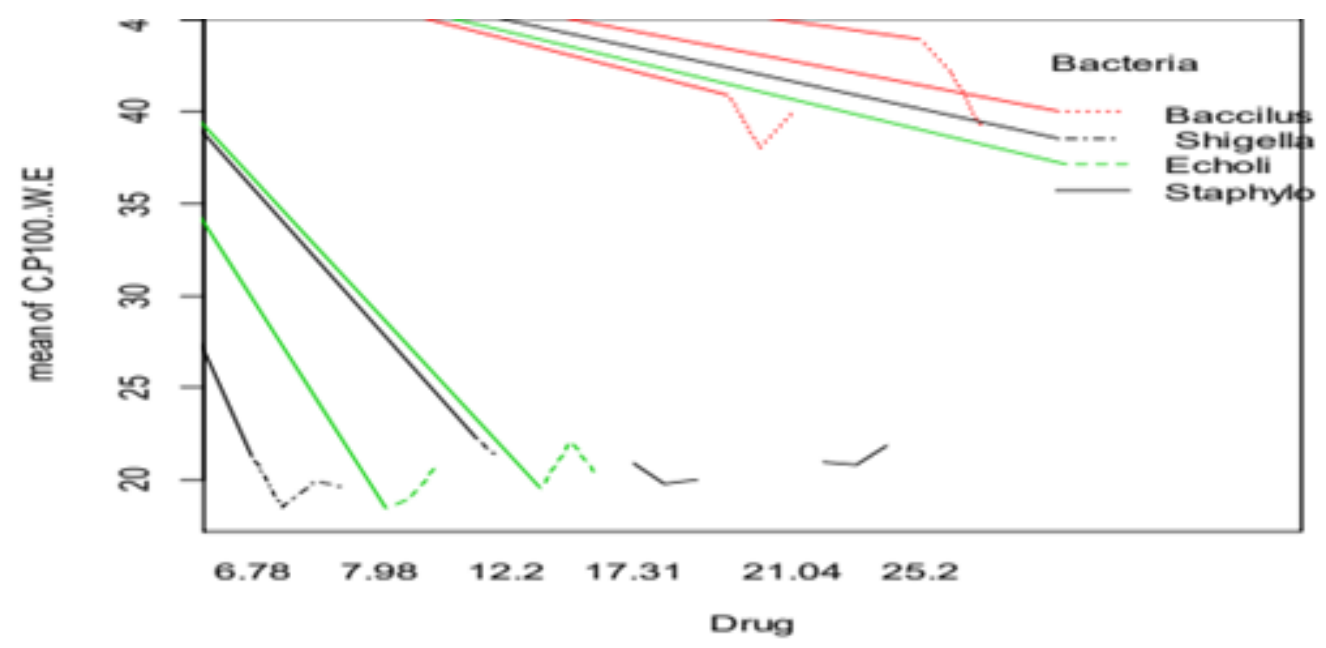

Figure 3

Interaction of Chloramphenicol, (Bacillus Subtilis, Staphylococcus aureus, Shigella boydii and Escherichia coli) and Croton pollen $100 \%$ concentrations of water extract

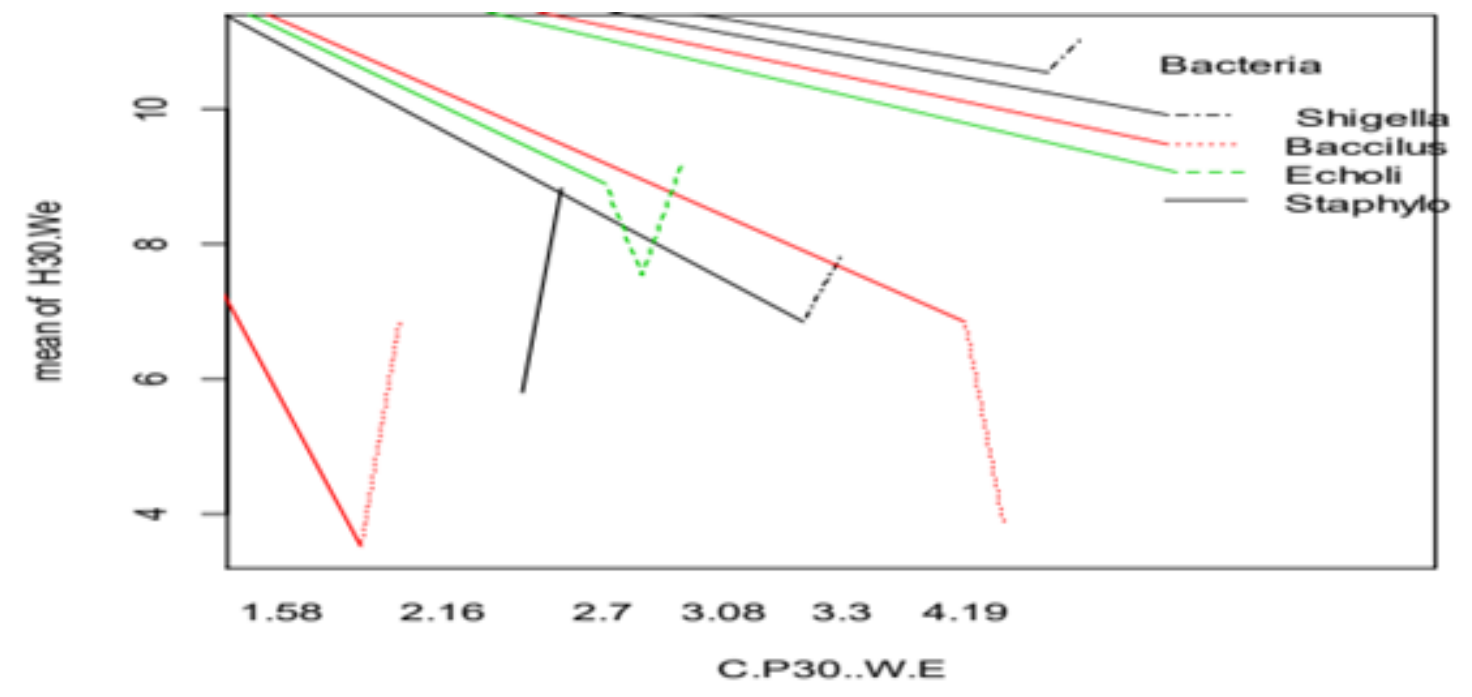

Figure 4

Interaction of Croton pollen 30\%, (Bacillus Subtilis, Staphylococcus aureus, Shigella boydii and Escherichia coli) and Honey $30 \%$ concentrations 


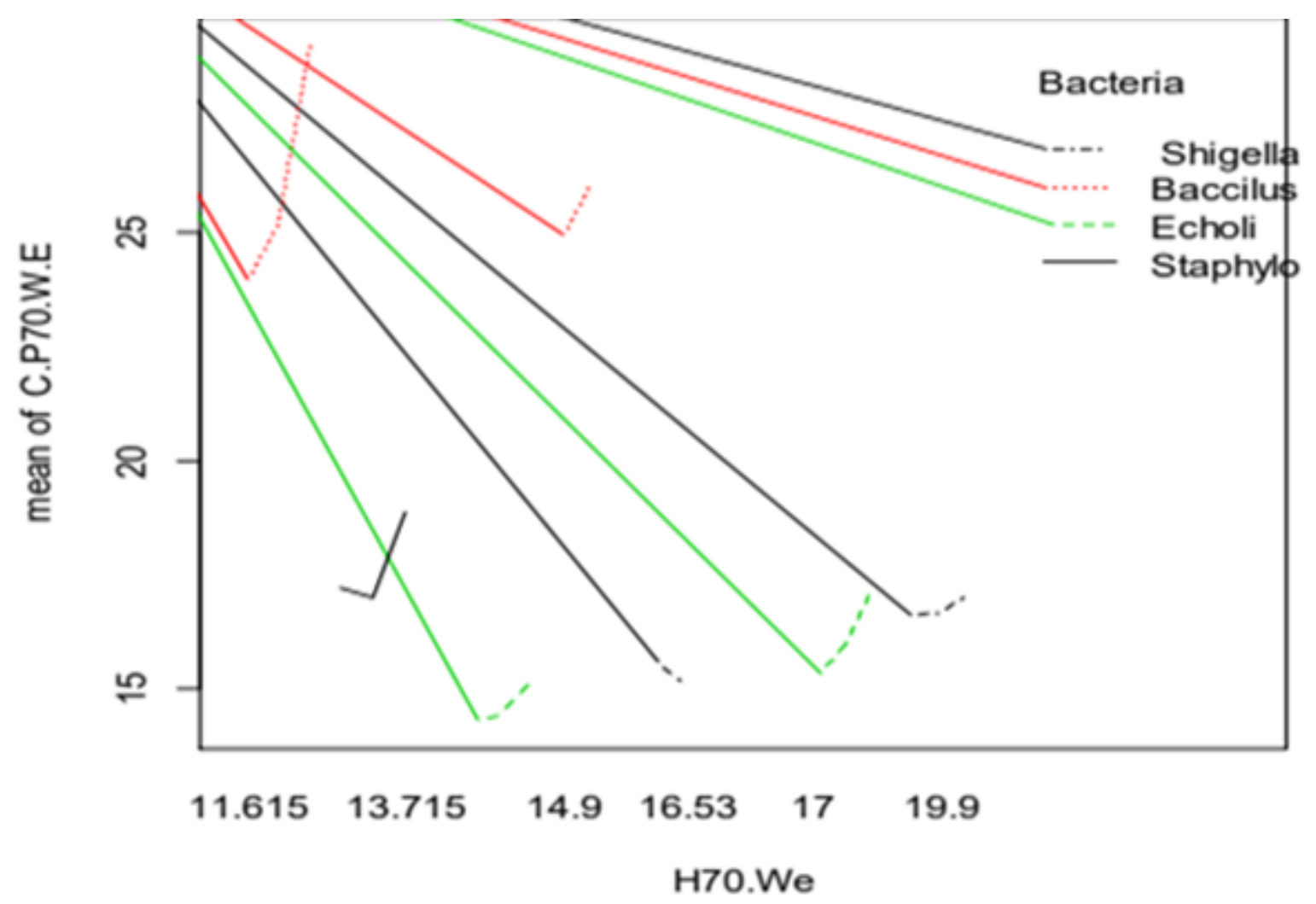

Figure 5

Interaction of honey $70 \%$ concentration, (Bacillus Subtilis, Staphylococcus aureus, Shigella boydii and Escherichia coli) and Croton pollen $70 \%$ concentrations of water extract

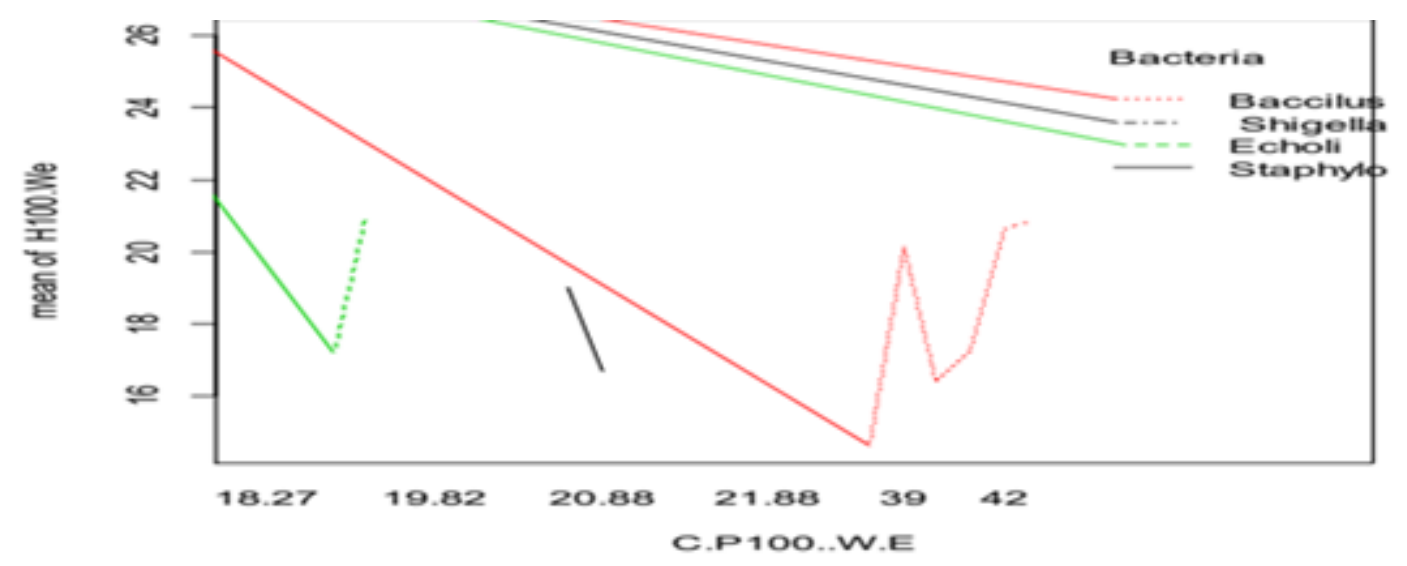

Figure 6

Interaction of Croton pollen 100\% concentrations, (Bacillus Subtilis, Staphylococcus aureus, Shigella boydii and Escherichia coli) and honey $100 \%$ concentration. 


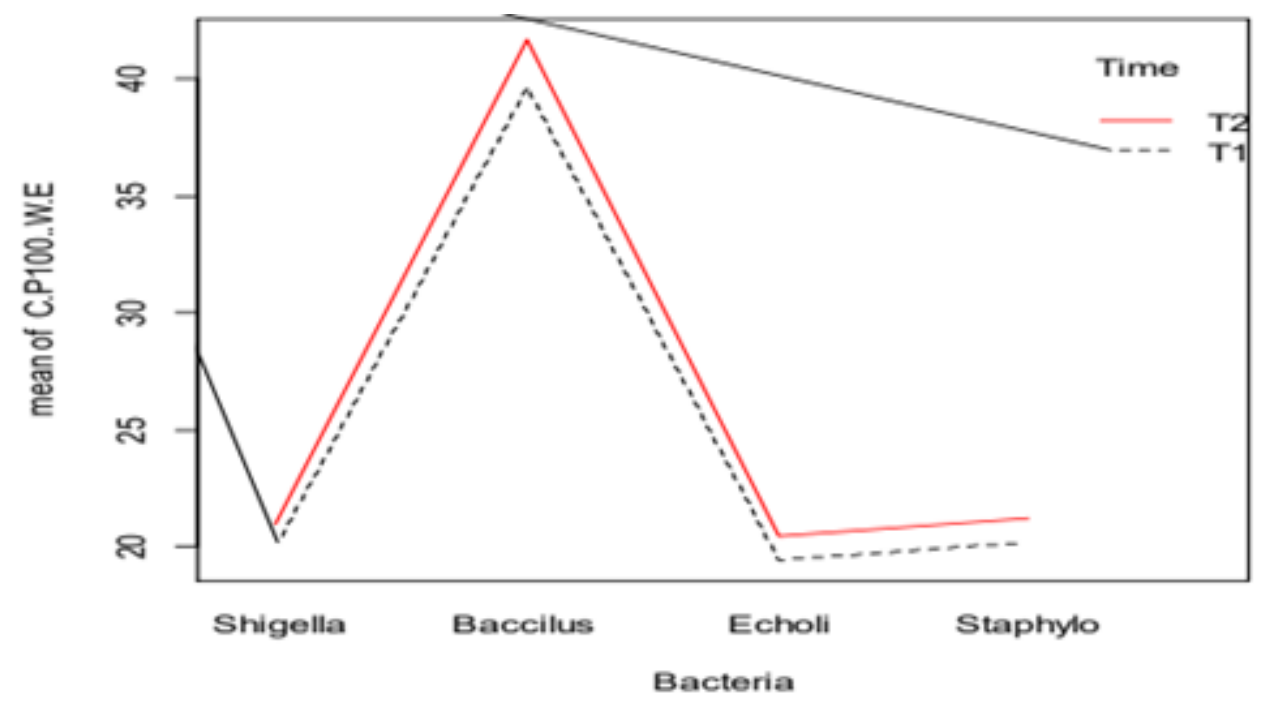

Figure 7

Interaction of, Bacillus Subtilis, Staphylococcus aureus, Shigella boydii and Escherichia coli, ( $\mathrm{T} 1=48$ hours and $\mathrm{T} 2=72$ and Croton pollen $100 \%$ concentration of water extracts.

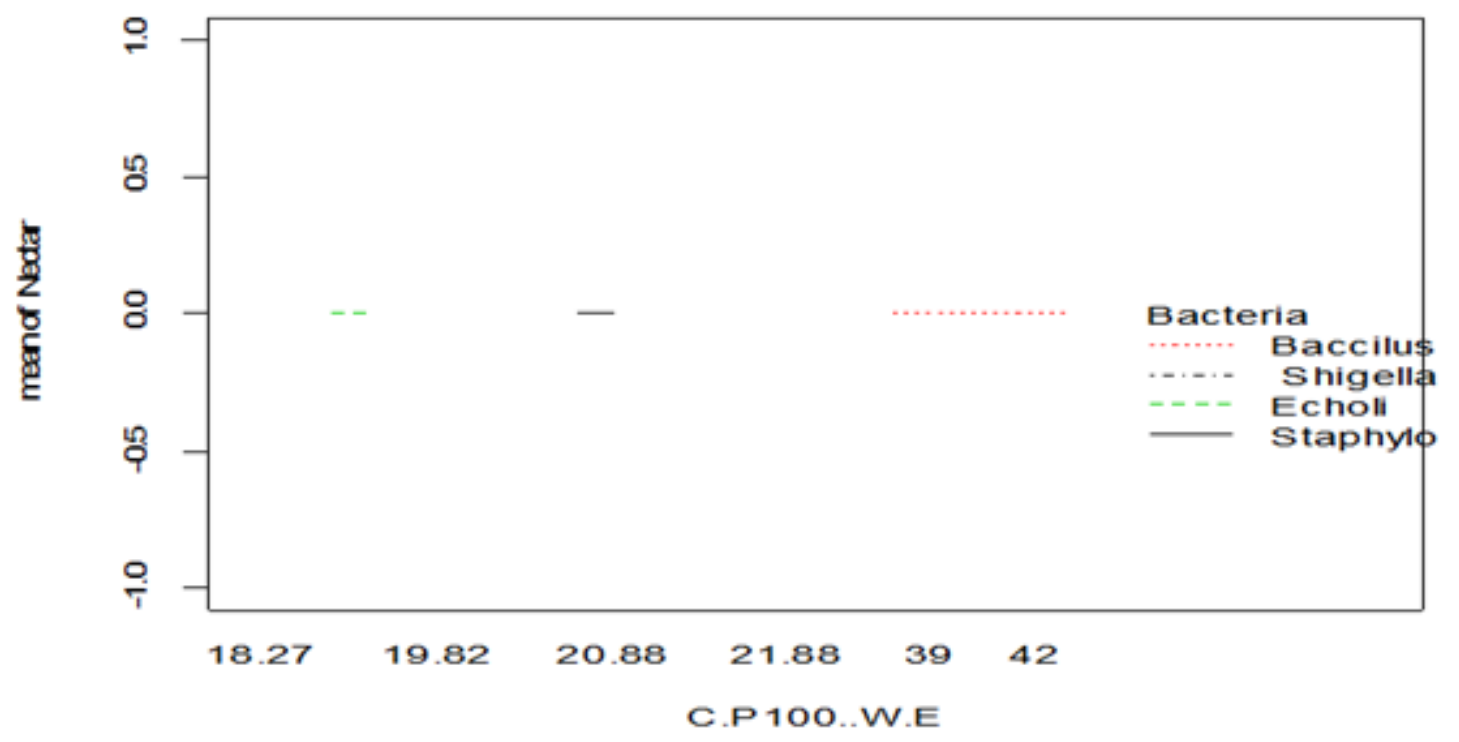

Figure 8

Interaction of Croton pollen 100\% concentration of water extracts, (Bacillus Subtilis, Staphylococcus aureus, Shigella boydii and Escherichia coli) and nectar. 


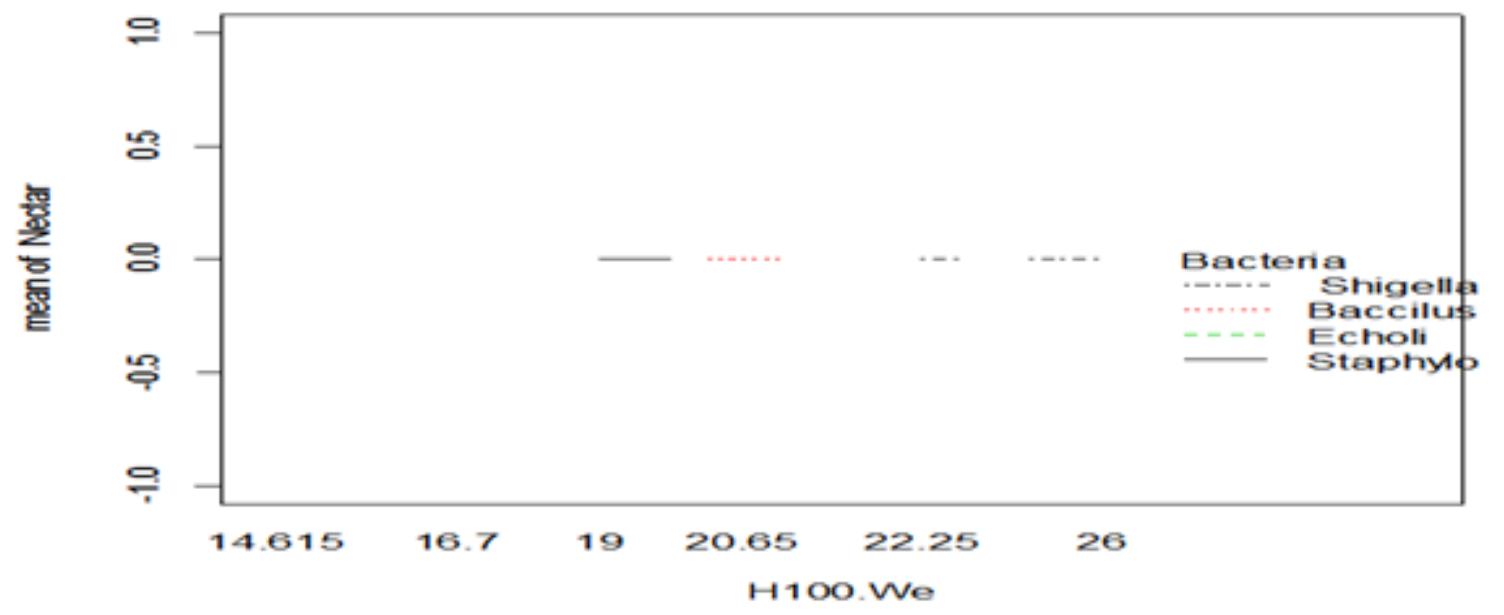

\section{Figure 9}

Interaction of honey $100 \%$ concentration, (Bacillus Subtilis, Staphylococcus aureus, Shigella boydii and Escherichia coli) and nectar

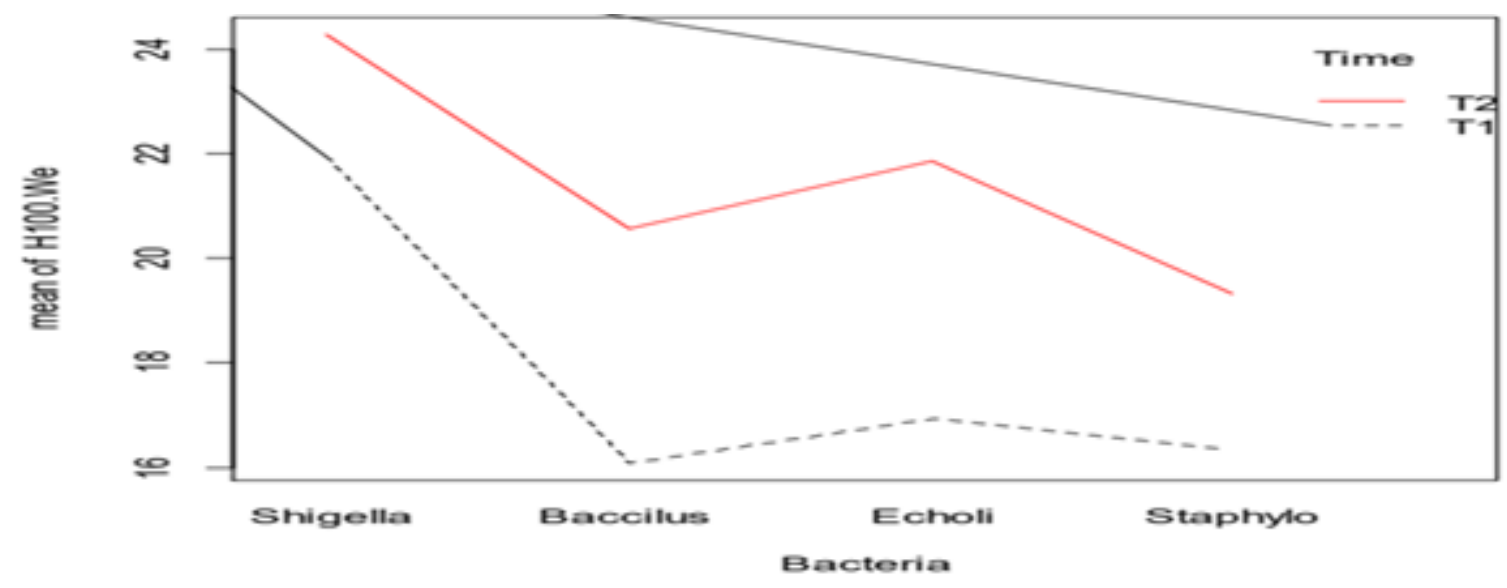

Figure 10

Interaction of, (Bacillus Subtilis, Staphylococcus aureus, Shigella boydii and Escherichia coli) time and nectar 